\title{
ANALISIS RAGAM MISKONSEPSI SISWA PADA KONSEP EFEK FOTO LISTRIK
}

\author{
Muhammad Habibbulloh \\ habibbullah@unisla.ac.id \\ Prodi Pendidikan IPA, FKIP, Universitas Islam Lamongan
}

\begin{abstract}
ABSTRAK
Penelitian ini bertujuan untuk menganalisis ragam miskonsepsi siswa yang muncul pada konsep efek fotolistrik. Penelitian dilakukan dengan memberikan tes diagnostik konsep efek fotolistrik setelah siswa mendapatakan pengajaran konvensional di kelas. Tes diagnostik yang diujikan terdiri atas pilihan ganda dilengkapi dengan alasan terbuka serta skala keyakinan jawaban (CRI) dan telah dinyatakan valid serta reliabel. Data yang didapatkan melalui tes diagnostik dianalisis berdasarkan kombinasi jawaban pilihan ganda dan CRI untuk mendapatkan kategori miskonsepsi dan lebih lanjut ragam miskonsepsi didapatkan melalui alasan terbuka yang dikemukakan. Hasil penelitian disimpulkan ragam miskonsepsi yang muncul pada siswa adalah: (1) panjang gelombang dan frekuensi sebanding,(2) panjang gelombang sebanding dengan energi cahaya,(3) besar energi cahaya dikacaukan dengan urutan warna pelangi,(4) menganggap jika energi cahaya sama dengan fungsi kerja, maka sudah terjadi efek fotolistrik, (5) frekuensi cahaya bertambah maka intensitas cahaya juga bertambah (6) tidak ada pengaruh intensitas cahaya terhadap Efek Fotolistrik,(7) stopping potential besarnya sama dengan energi cahaya.
\end{abstract}

Kata kunci : Miskonsepsi, Tes Diagnostik, Efek Foto listrik

\section{PENDAHULUAN}

Siswa hadir di sekolah dengan bermacam-macam pengalaman dan ide atau pemikiran tentang materi pembelajaran berdasarkan perilaku alamiah sehari-hari (Berg,1991). Keluasan ide tersebut berbeda dengan latar belakang siswa dan biasanya berbeda dengan ide-ide yang dimiliki ilmuan. Perbedaan kerangka berpikir tersebut telah di deskripsikan sebagai miskonsepsi (Fisher, 1985), konsepsi alternatif (Amaudin, Mintzes, 1985), prakonsepsi (Gallegos, Jerezano, \& Flores, 1994), kerangka berpikir alternatif (Driver, 1981), ide-ide yang salah (Sanders, 1993), dan science anak-anak (Gilbert, Osborne \& Fenshman,1982). "Miskonsepsi" untuk menyatakan ide-ide atau pemikiran yang dimiliki siswa yang tidak konsisten atau mengandung konflik dengan generalisasi ide-ide yang diterima oleh ilmuan (Tekkaya, 2002)

Miskonsepsi merupakan salah satu masalah yang ditemui pada berbagai tingkat satuan pendidikan dan latar belakang. Hal tersebut dapat didiagnosis dari Tes Diagnostik miskonsepsi yang diberikan kepada setiap siswa. Setiap orang dapat mengalami miskonsepsi. Uzun, Alev, dan Karal (2013) menyatakan bahwa miskonsepsi pada konsep cahaya, sumber cahaya, dan proses melihat telah terjadi pada semua level usia. Pablicio (2010) dalam penelitiannya juga menyatakan bahwa siswa Amerika memiliki kesulitan konseptual pada gaya dan gravitasi yang mirip dengan siswa di Asia-Pasifik. Bayraktar (2009) juga menyatakan bahwa calon guru fisika di turky juga mengalami miskonsepsi pada konsep gaya dan gerak.

Miskonsepsi adalah pengertian yang tidak akurat akan konsep, penggunaan konsep yang salah, klasifikasi contohcontoh yang salah, kekacauan konsepkonsep yang berbeda dan hubungan hierarkis konsep-konsep yang tidak benar (Suparno, 2005).

Novak \& Gowin (1984) menyatakan bahwa miskonsepsi merupakan suatu interpretasi konsep-konsep dalam suatu pernyataan yang tidak dapat diterima. 
Miskonsepsi adalah salah satu masalah dalam proses belajar mengajar fisika di sekolah. Pembelajaran konvensional dan sifat abstrak materi pembelajaran turut meningkatkan resiko terjadi miskonsepsi. Pembelajaran konvensional adalah pembelajaran yang biasa digunakan guru di kelas. Miskonsepsi siswa yang muncul pada efek fotolistrik belum pernah terdeteksi hingga saat ini, sehingga kreativitas dalam menggunakan metode yang tepat untuk mengajarkan topik efek fotolistrik tidak berkembang dari waktu ke waktu dan cenderung stagnan tanpa adanya solusi yang tepat.

Efek fotolistrik adalah salah satu konsep dalam fisika modern yang diajarkan pada tingkat menengah atas di Indonesia. Konsep efek fotolistrik sangat abstrak karena tidak bisa diamati secara langsung proses keluarnya elektron maupun aliran elektron pada rangkaian (Klassen, 2009). Hal ini adalah salah satu yang menyebabkan muncul miskonsepsi siswa pada topik efek fotolistrik.

Efek fotolistrik memainkan peran penting untuk membantu siswa membangun pemahaman tentang model foton cahaya (wong, et al., 2011). Efek fotolistrik adalah suatu fenomena dimana elektron pada logam katoda yang ditempatkan diruang vakum teremisi keluar pada anoda sehingga menghasilkan arus listrik. Untuk mengemisikan fotoelektron, energi cahaya yang datang harus lebih besar daripada fungsi kerja logam (wong, et al., 2011).

Karakteristik konsep efek fotolistrik yang abstrak tersebut, membuat potensi siswa mengalami miskonsepsi sangat tinggi. Oleh karena itu, untuk langkah penanganan miskonsepsi lebih lanjut, peneliti akan memetakan jenis miskonsepsi yang muncul melalui analisis ragam miskonsepsi siswa pada konsep efek fotolistrik.

\section{METODE PENELITIAN}

Metode yang digunakan dalam penelitian ini adalah one-shot case study (Sugiyono, 2015). Siswa diberikan tes diagnostik setelah diberikan pembelajaran efek fotolistrik secara konvensional. Tes diagnostik diberikan kepada 36 siswa SMA labschool Unesa di Surabaya yang diambil secara acak secara simple random sampling (Sugiyono, 2015). Instrumen yang digunakan dalam penelitian adalah soal tes diagnostik sebanyak 15 soal pilihan ganda dilengkapi dengan CRI (Certainty of Response Index) skala 5 yang menunjukkan tingkat keyakinan siswa menjawab soal tes diagnostik dan alasan terbuka (open reasoning) yang digunakan untuk memperkuat jawaban siswa (Hassan, S., Bagayoko, D., \& Kelley, E.L, 1999). Soal tes diagnostik yang sudah diuji dinyatakan valid dan reliabel untuk digunakan (Habibbulloh, et.al, 2017). Rincian sub materi yang diuji pada tes diagnostik adalah sebagai berikut: soal nomor 1 dan 2 menguji tentang hubungan panjang gelombang dan frekuensi, soal nomor 3 dan 4 menguji tentang hubungan panjang gelombang dengan energi fotoelektron, soal nomor 5 dan 6 menguji tentang besar energi cahaya tampak, soal nomor 7 dan 8 menguji tentang hubungan energi cahaya dan energi ambang terhadap emisi fotoelektron, soal nomor 9 menguji tentang pengaruh energi cahaya terhadap intensitas fotoelektron, soal nomor 10 hingga 13 menguji tentang pengaruh intensitas cahaya, dan soal nomor 14 dan 15 tentang stopping pottential.

Jawaban soal tes diagnostik dikategorikan dalam 4 kuadran sebagai berikut: (1) Tahu konsep, apabila jawaban benar dan skala CRI tinggi (3, 4, atau 5), (2) Lucky Guess, apabila jawaban benar dan skala CRI rendah (0,1, atau 2), (3) Tidak Tahu Konsep, apabila jawaban salah dan skala CRI rendah (0,1, atau 2), (4) 
Miskonsepsi, apabila jawaban salah dan skala CRI tinggi $(3,4$, atau 5$)$.

Data analisis diperoleh dari soal tes diagnostik sehingga menghasilkan grafik CRI benar (CRIB) dan CRI salah (CRIS) beserta fraksi benar jawaban siswa. CRIB diperoleh berdasarkan rata-rata nilai CRI untuk jawaban benar, sedangkan CRIS diperoleh berdasarkan rata-rata nilai CRI untuk jawaban salah. Fraksi Benar (FB) diperoleh berdasarkan hasil bagi antara siswa yang menjawab benar dengan jumlah total siswa. Analisis jawaban Tes Diagnostik dilanjutkan dengan kategorisasi jawaban siswa berdasarkan 4 kategori. Jawaban siswa dengan kategori Miskonsepsi selanjutnya diperkuat dengan analisis kualitatif jawaban alasan terbuka untuk ditabulasikan berdasarkan miskonsepsi yang muncul.

\section{HASIL DAN PEMBAHASAN}

Hasil yang didapatkan dari analisis penggolongan tes diagnostik dilihat pada gambar 1 .

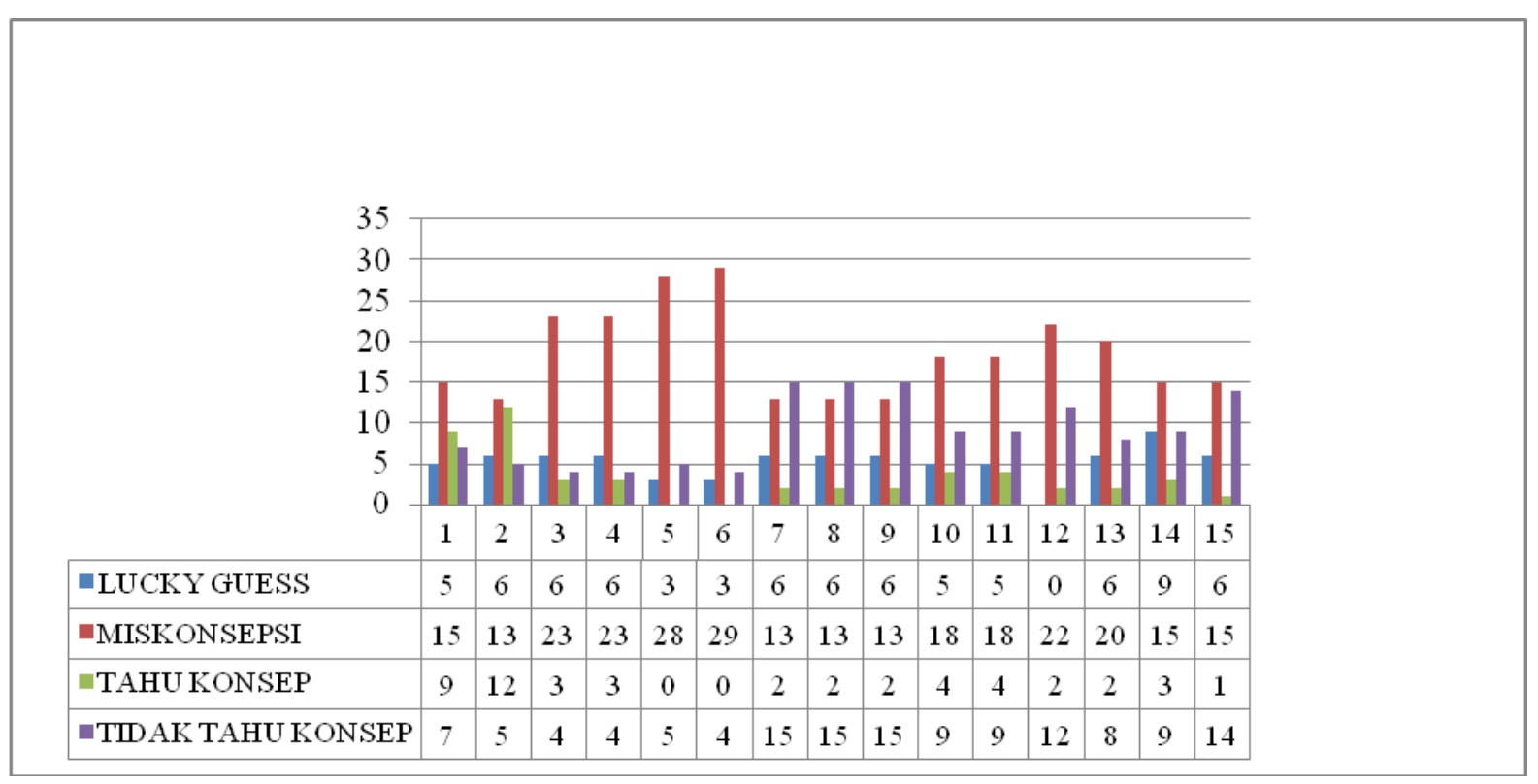

Gambar 1. Hasil Kategorisasi Tes Diagnostik

Berdasarkan gambar 1 terlihat bahwa siswa mengalami miskonsepsi di setiap soal tes diagnostik dengan jumlah variatif. Misalkan pada soal 1 , sebanyak 15 siswa mengalami miskonsepsi, 9 siswa tahu konsep, 7 siswa tidak tahu konsep, dan 5 siswa berkategori lucky guess. Berturut- turut siswa yang mengalami miskonsepsi pada tiap soal terlihat secara horizontal pada baris kategori miskonsepsi Data yang didapatkan selanjutnya adalah berdasarkan jumlah siswa menjawab benar dan salah dikombinasikan dengan CRI benar dan CRI salah didapatkan: 


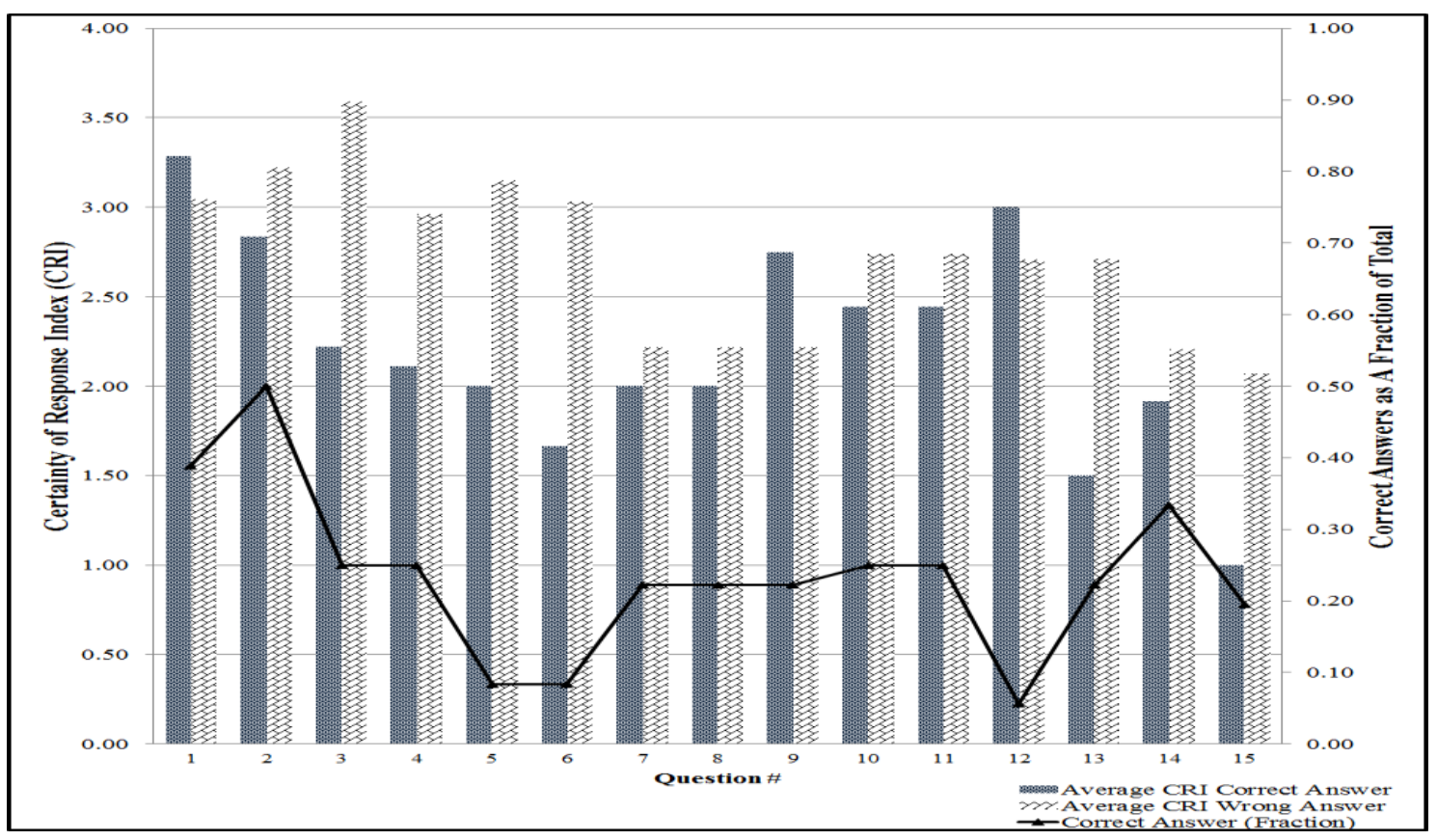

Gambar 2. Grafik CRI Benar \& CRI Salah dengan Plot Fraksi Benar

Berdasarkan analisis grafik pada Gambar 2, terlihat bahwa CRI Salah yang tinggi dikombinasikan dengan fraksi benar (Fraksi siswa yang menjawab jawaban benar) yang relatif rendah (di bawah 0,5 ) menunjukkan eksistensi miskonsepsi disetiap soal tes diagnostik yang diujikan mulai nomor 1 hingga 15 .
Analisis lebih lanjut berdasarkan alasan terbuka dari jawaban tes diagnostik dapat ditabulasi ragam miskonsepsi berdasarkan data tes diagnostik didapatkan persentase dan jenis miskonsepsi yang ditemukan. Persentase miskonsepsi yang muncul berdasarkan jenis miskonsepsi dapat dilihat pada Tabel 1 berikut.

Tabel 1. Tabulasi Ragam miskonsepsi yang muncul beserta persentase

\begin{tabular}{|c|c|c|}
\hline No. & Miskonsepsi & Persentase \\
\hline 1. & $\begin{array}{l}\text { Siswa cenderung menganggap panjang gelombang dan frekuensi sebanding.(nomor } 1 \\
\text { dan 2) }\end{array}$ & $55,56 \%$ \\
\hline 2. & $\begin{array}{l}\text { Siswa menganggap panjang gelombang dan energi fotoelektron sebanding atau frekuensi } \\
\text { berbanding terbalik dengan energi fotoelektron. (nomor } 3 \text { dan } 4 \text { ) }\end{array}$ & $75,00 \%$ \\
\hline 3. & $\begin{array}{l}\text { Siswa miskonsep antara besar energi cahaya tampak dengan warna pelangi.(nomor } 5 \text { dan } \\
6 \text { ) }\end{array}$ & $91,67 \%$ \\
\hline 4. & $\begin{array}{l}\text { Siswa menganggap jika energi cahaya sama dengan energi ambang maka elektron akan } \\
\text { keluar teremisi, faktanya elektron tepat akan keluar atau tidak ada elektron yang } \\
\text { teremisi. (nomor } 7 \text { dan } 8 \text { ) }\end{array}$ & $77,78 \%$ \\
\hline 5. & $\begin{array}{l}\text { Siswa menganggap jika frekuensi cahaya bertambah maka intensitas cahaya juga } \\
\text { bertambah, faktanya frekuensi cahaya tidak berpengaruh terhadap intensitas cahaya } \\
\text { (Krane,1992).(nomor 9) }\end{array}$ & $77,78 \%$ \\
\hline 6. & $\begin{array}{l}\text { Siswa menganggap ada pengaruh intensitas cahaya terhadap efek fotolistrik saat } \\
\text { frekuensi cahaya di bawah frekuensi ambang. Faktanya, intensitas hanya berpengaruh } \\
\text { jika frekuensi cahaya berada di atas frekuensi ambang. ( nomor 10,11,12, dan 13) }\end{array}$ & $80,56 \%$ \\
\hline 7. & $\begin{array}{l}\text { Siswa menganggap bahwa stopping potensial besarnya sama dengan energi cahaya yang } \\
\text { datang.(nomor } 14 \text { dan } 15 \text { ) }\end{array}$ & $73,61 \%$ \\
\hline
\end{tabular}

Berikut ditampilkan contoh analisis jawaban terbuka yang diberikan siswa pada tes diagnostik dapat dilihat pada Gambar 3 dan Gambar 4. 


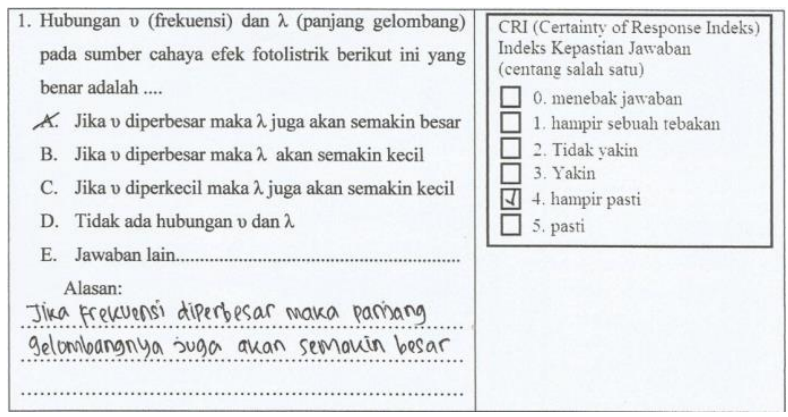

Gambar 3. Jawaban dengan kategori

miskonsepsi dengan ragam: siswa cenderung menganggap panjang gelombang dan frekuensi sebanding

\section{KESIMPULAN}

Berdasarkan analisis data tes diagnostik dihasilkan beberapa poin penting melalui analisis kategori miskonsepsi Gambar 1, terlihat kategori miskonsepsi sangat mendominasi hasil tes diagnostik. Keberadaan miskonsepsi yang sangat tinggi terlihat pula dari grafik pada Gambar 2 dimana tingginya level CRI salah (keyakinan siswa yang menjawab jawaban salah) yaitu siswa meyakini bahwa jawaban yang diberikan adalah benar namun fakta yang terjadi jawaban siswa salah, dikombinasikan dengan fraksi jawaban benar yang relatif rendah (di bawah level 0,5) menunjukkan bahwa eksistensi miskonsepsi di setiap nomor soal yang diujikan adalah sangat tinggi. Selanjutnya setelah dikombinasi dengan analisis jawaban terbuka dari tes diagnostik dapat ditabulasikan ragam miskonsepsi yang terjadi pada siswa berdasarkan nomor soal yang diberikan. Dari penggabungan analisis kategori jawaban tes diagnostik, grafik CRI dan Fraksi benar, serta analisis jawaban terbuka siswa, dapat disimpulkan ragam miskonsepsi yang terjadi pada konsep efek

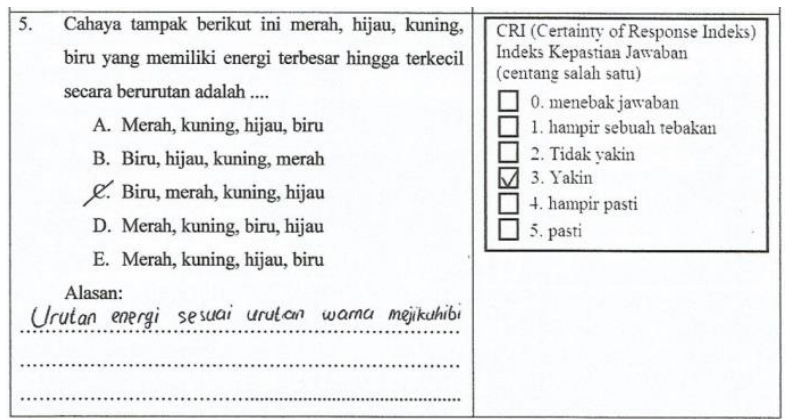

Gambar 4. Jawaban dengan kategori

Miskonsepsi dengan ragam: siswa miskonsep antara besar energi cahaya tampak dengan warna pelangi.

fotolistrik adalah: (1) siswa cenderung menganggap panjang gelombang dan frekuensi sebanding, (2) siswa menganggap panjang gelombang dan energi fotoelektron sebanding atau frekuensi berbanding terbalik dengan energi fotoelektron, (3) siswa miskonsep antara besar energi cahaya tampak dengan warna pelangi, (4) siswa menganggap jika energi cahaya sama dengan energi ambang maka elektron akan keluar teremisi, faktanya elektron tepat akan keluar atau tidak ada elektron yang teremisi, (5) siswa menganggap jika frekuensi cahaya bertambah maka intensitas cahaya juga bertambah, faktanya frekuensi cahaya tidak berpengaruh terhadap intensitas cahaya, (6) siswa menganggap ada pengaruh intensitas cahaya terhadap efek fotolistrik saat frekuensi cahaya di bawah frekuensi ambang. Faktanya, intensitas hanya berpengaruh jika frekuensi cahaya berada di atas frekuensi ambang., (7) siswa menganggap bahwa stopping potensial besarnya sama dengan energi cahaya yang datang. 


\section{DAFTAR PUSTAKA}

Amaudin, M. W., \& Mintzes, J. J. 1985. Students' alternative conceptions of the human circulatory system: Across age study. Science Education, 69(5),721-733.

Bayraktar, S. 2009. Misconceptions of Turkish Pre-Service Teachers about Force and Motion. International Journal of Science and Mathematics Education. 7: 273-291.

Berg, Euwe Van Den. 1991. Miskonsepsi fisika dan Remediasi. Salatiga: Universitas Kristen Satya Wacana.

Driver, R. 1981. Pupils' alternative frameworks in seience. European Journal of Seience Education, 3(1),93-101.

Finegold, M., \& Grosky, P. 1988. Learning about forces: Simulating the outcomes of pupils' misconceptions.Physics all Science, 17, 251-261.

Fisher, K. M. 1985. A miseoneeption in biology: Amino acids and translation. Journal of Researeh in Seience Teaehing, 22(1), 63-72.

Gallegos, L., Jerezano, M.E. \& Flores, F. (1994).Preconceptions and relations used by children in the construction of food chains. Journal ofResearch in Science Teaching, 31(3), 259-272.

Habibbulloh, M., Jatmiko,B., dan Widodo, W. 2017. Pengembangan Perangkat Pembelajaran Model Guided Discovery Berbasis Lab Virtual untuk Mereduksi Miskonsepsi Siswa
SMK Topik Efek Fotolistrik. JPFA (Jurnal Pendidikan Fisika dan Aplikasi).

Doi:http://dx.doi.org/10.26740/jpfa.v 7n1.p27-43.

Hassan, S., Bagayoko, D., \& Kelley, E.L. 1999. Misconceptions and the Certainty of Response Index (CRI). Article in Physics Education . September $1999 . \quad$ DOI: 10.1088/0031-9120/34/5/304

Klassen, Stephen. 2009. The Photoelectric Effect: Reconstructing the Story for the Physics Classroom. Published Online $($ ) Springer Science+Business Media B.V. DOI 10.1007/s111910009-9214-6

Krane, Kennet \& Hans J. Wospakrik.1992. Fisika Modern. Penerbit Universitas Indonesia UI-Press:Jakarta.

Novak, J.D. \& Gowin, D.B. 1984. Learning How to Learn. Cambridge: Cambridge University Press.

Pablicio, J.R. 2010. Misconceptions on Force and Gravity Among High School Students (A Thesis Master of Natural Sciences). The Interdepartmental Program in Natural Sciences: Louisiana State University.

Sugiyono. 2015. Metode Penelitian Pendidikan (Pendekatan Kuantitatif, Kualitatif, dan $R \& D)$. Bandung: Alfabeta.

Suparno, Paul. 2005. Miskonsepsi dan Perubahan Konsep dalam Pendidikan Fisika. Jakarta: Gramedia Widiasarana Indonesia. 
Tekkaya, Ceren. 2002. Misconceptions as Barrier to Understanding Biology. Hacettepe Universitesi Egitim Fakultesi Dergisi 23: (259 - 266) (2002) Turkey

Uzun, S., Alev, N., Karal, I.S. 2013. A Cross-Age Study of An Understanding Of Light and Sight Concepts in Physics. Science Education International. Vol. 24, Issue 2, 2013, 129 - 149.
Wong, D., Lee, P., Shenghan, G., Xuezhou, W., Yan Qi, H., See Kit, F. 2011. The Photoelectric Effect: Experimental Confirmation Concerning A Widespread Misconception in The Theory. IOP PUBLISHING: European Journal of Physics. Eur. J. Phys. 32 (2011) 1059-1064. doi:10.1088/01430807/32/4/018 